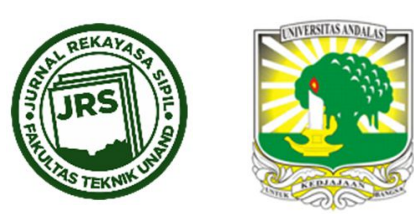

\title{
EVALUASI DAN PERENCANAAN LAMPU LALU LINTAS PADA SIMPANG JALAN SYEKH UMAR KHALIL-BYPASS KOTA PADANG
}

\author{
TITI KURNIATI ${ }^{1}$, ABDUL LATIF $^{1}$, ELSA EKA PUTRI ${ }^{\left.1^{*}\right)}$ \\ ${ }^{1}$ Jurusan Teknik Sipil, Fakultas Teknik, Universitas Andalas \\ *Corresponding author: $ه$ elsaeka@eng.unand.ac.id
}

Naskah diterima : 20 Maret 2020. Disetujui: 11 April 2020.

\begin{abstract}
ABSTRAK
Kemacetan yang sering terjadi pada simpang Jalan Syekh Umar Khalil-Bypass Kota Padang menimbulkan terjadinya antrian dan tundaan pada salah satu simpang yang sangat panjang. Maka dilakukanlah evaluasi dan perencanaan lampu lalu lintas untuk mangatasi permasalahan yang terjadi. Survei dilakukan dengan merekam lalu lintas kendaraan dengan menggunakan kamera yang ditempatkan pada persimpangan. Pengambilan data dilaksanakan selama enam jam setiap hari selama dua hari kerja, yaitu 2 jam pagi hari (pukul 07.00 - 09.00), 2 jam siang hari (pukul 12.00 14.00), dan 2 jam sore hari (pukul 16.00 - 18.00) pada hari Senin dan Kamis. Kemudian tiap jalur dibagi menjadi beberapa sektor sesuai dengan arah jalan per 15 menit. Dari data per 15 menit tersebut direkap dalam 1 jam, lalu diambil jam puncaknya untuk dianalisa. Perhitungan parameter perencanaan berdasarkan MKJI 1997. Hasil yang didapat pada kondisi eksisting untuk nilai derajat kejenuhan masing-masing pendekat Utara, Selatan dan Timur telah melewati batas jenuh (DS $>0,75)$, sehingga diusulkan 4 jenis perancangan untuk meningkatkan kinerja simpang. Alternatif 1 , pelebaran jalur pendekat, alternatif 2, pengaturan simpang menjadi 2 fase, alternatif 3 , pengaturan simpang 2 fase dan pelebaran sedangkan alternatif 4 adalah dengan menutup simpang. Hasil perhitungan menunjukan, perencanaan optimum adalah alternatif 3 dan 4 .
\end{abstract}

Kata kunci : Lampu Lalulintas, Derajat Kejenuhan, Panjang Antrian, Tundaan

\section{PENDAHULUAN}

Volume lalu lintas yang padat terjadi di simpang Jalan Syekh Umar Khalil-Bypass Kota Padang seperti yang terlihat pada Gambar 1. Persimpangan ini merupakan salah satu akses jalan ke perkantoran seperti kantor Balai Kota, Rumah Sakit Baiturrahmah dan perkantoran lainnya.

Jalan Bypass ini tergolong jalan Arteri sebagai lengan mayor sedangkan jalan Syekh Umar Khalil merupakan jalan kolektor sebagai lengan minor. Kemacetan sering terjadi sehingga diperlukan evaluasi serta perencanaan ulang waktu lalu lintas berdasarkan volume dan arus jenuh dengan perhitungan MKJI 1997. 
Penelitian ini bertujuan untuk mengevaluasi kinerja simpang ber-APILL (alat pemberi isyarat lalu lintas), dan merencanakan ulang alat pemberi isyarat lalu lintas pada Jalan Syekh Umar Khalil-Bypass Kota Padang sehingga tundaan dan antrian bisa dikurangi. Penelitian dilakukan pada 2 jam pagi, siang dan sore, pada saat sering terjadinya penumpukan lalu lintas (Mahendra, Khairi, Arifin, \& Sulistio, 2015). Pengaturan simpang bersinyal perlu dievaluasi setiap tahun karena pertumbuhan jumlah kendaraan bermotor pertahunnya tinggi (Khairunnisa, EPF, Priyono, \& Supriyono, 2017; Pradipta, Eka, \& Purba, 2016).
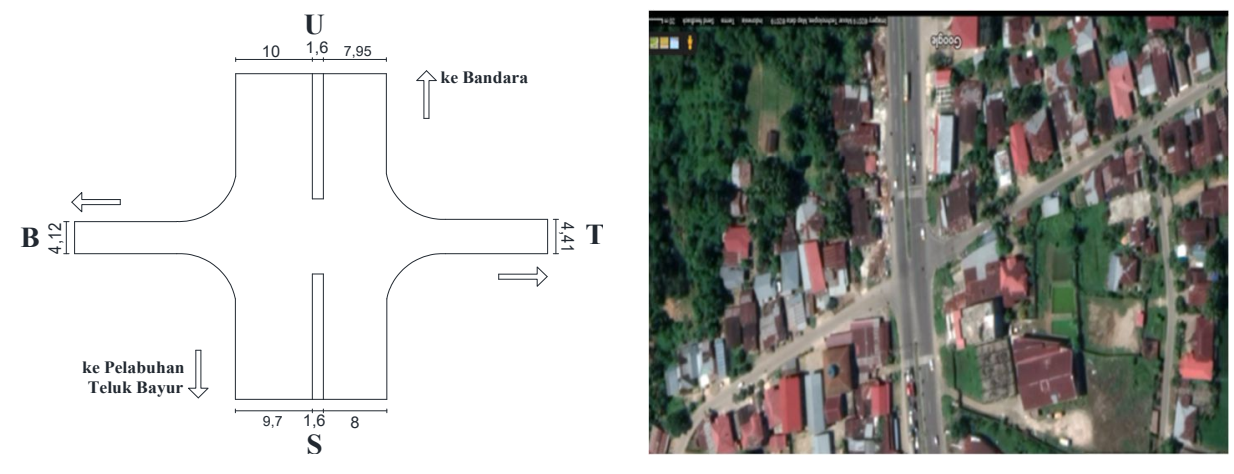

Gambar 1. Lokasi Penelitian (Simpang Jalan Syekh Umar Khalil-Bypass Kota Padang)

Manfaat dari penelitian ini adalah sebagai bahan referensi dan pertimbangan bagi pihak yang berwenang dalam perancangan lampu lalu lintas, untuk mengurangi permasalahan lalu lintas pada persimpangan Jalan Syekh Umar Khalil-Bypass Kota Padang.

\section{PERSIMPANGAN JALAN DAN LAMPU LALU LINTAS}

\subsection{Persimpangan Jalan}

Menurut PP 43/1993 tentang Prasarana dan Lalu Lintas Jalan, simpang adalah pertemuan atau percabangan jalan sebidang dan tempat berbelok atau bercabang dari yang lurus. AASHTO (Khisty \& Lall, 2005) mendefinisikan persimpangan sebagai daerah umum, dimana dua jalan atau lebih bergabung atau bersimpangan, termasuk jalan dan fasilitas tepi jalan untuk pergerakan lalu-lintas didalamnya.

\subsection{Simpang Bersinyal}

Menurut MKJI 1997, simpang bersinyal merupakan bagian dari sistem kendali waktu tetap yang dirangkai, biasanya dianalisa dengan metoda dan perangkat lunak khusus untuk menentukan waktu sinyal, kapasitas dan perilaku lalu lintas seperti tundaan, panjang antrian, dan rasio kendaraan terhenti pada simpang bersinyal di daerah perkotaan maupun semi perkotaan. Penggunaan sinyal dengan lampu tiga warna (hijau, kuning, merah) diterapkan untuk memisahkan lintasan dari gerakan-gerakan lalu-lintas yang saling bertentangan dalam dimensi waktu (Direktorat Jendral Bina Marga, 1997; Munandar, 2012; Royan, 2015).

\subsection{Lampu Lalu Lintas}

Lampu lalu lintas adalah sebuah alat elektrik dengan sistem pengatur waktu yang memberikan hak jalan pada satu arus lalu-lintas atau lebih sehingga aliran lalu-lintas ini bisa melewati persimpangan dengan aman dan efisien (Khisty \& Lall, 2005; Utama, Sumanjaya, \& Ardantha, 2017). 
Terdapat beberapa keuntungan dan kerugian merancang lampu lalu lintas di persimpangan. Keuntungannya dapat mengurangi frekuensi tipe kecelakaan tertentu, khususnya kecelakaan tipe sudut kanan; menghasilkan pergerakan lalu lintas yang teratur; menyediakan arus yang kontinu bagi iringan-iringan kendaraan melalui kordinasi yang memadai pada kecelakaan tertentu di rute tertentu; memungkinkan kendaraan dan pejalan kaki untuk melintasi lalu lintas yang sangat ramai; serta pengendalian lalu lintas menjadi lebih ekonomis dibandingkan metode manual. Sedangkan kerugiannya dapat meningkatkan frekuensi kecelakaan; penundaan yang terlalu lama; pelanggaran lampu lalu lintas; dan perjalanan memutar melalui rute alternative (Khisty \& Lall, 2005).

Khisty and Lall (2005) mengungkapkan bahwa pemasangan lampu lalu lintas untuk meningkatkan keamanan sistem secara keseluruhan, mengurangi waktu tempuh rata-rata dan menyeimbangkan kualitas pelayanan di seluruh aliran lalu lintas.

\subsection{Bukaan Median}

Bukaan median digunakan sebagai fasilitas kendaraan untuk memutar menuju arus sebaliknya dan kendaraan harus menunggu untuk tersedianya gap yang aman pada arus utama. Aturan mengenai dimensi bukaan median jalan untuk daerah perkotaan dan luar kota terdapat pada Tabel 1.

Tabel 1. Dimensi Geometrik Bukaan Pemisah Jalur

\begin{tabular}{ccccccc}
\hline \multirow{2}{*}{$\begin{array}{c}\text { Fungsi Jalan } \\
\text { Utama }\end{array}$} & \multicolumn{2}{c}{ Daerah perkotaan (satuan dalam meter) } & \multicolumn{3}{c}{ Daerah luar kota (satuan dalam } \\
\cline { 2 - 7 } & $\begin{array}{c}\text { Jarak } \\
\text { Bukaan } \\
\text { Minimum }\end{array}$ & $\begin{array}{c}\text { Lebar } \\
\text { Bukaan }\end{array}$ & $\begin{array}{c}\text { Panjang } \\
\text { Bukaan }\end{array}$ & $\begin{array}{c}\text { Jarak } \\
\text { Bukaan } \\
\text { Minimum }\end{array}$ & $\begin{array}{c}\text { Lebar } \\
\text { Bukaan }\end{array}$ & $\begin{array}{c}\text { Panjang } \\
\text { Bukaan }\end{array}$ \\
\hline Arteri & 400 & 6 & 12 & 500 & 6 & 12 \\
\hline Kolektor & 300 & 5 & 10 & 400 & 5 & 10 \\
\hline
\end{tabular}

Sumber : SNI 2444:2008

Pada penelitian ini dititik beratkan pada pengaturan sinyal. Sedangkan pada bukaan median tidak dianalisa tentang ketersedian gap untuk lalu lintas berputar arah pada lalu lintas ini.

\subsection{Perhitungan Menurut MKJI}

\subsubsection{Kapasitas dan Derajat Kejenuhan}

Kapasitas ruas jalan dihitung berdasarkan rumus (1) merupakan kemampuan dari ruas jalan yang berfungsi untuk menampung arus atau volume lalu lintas yang ideal, berdasarkan jumlah kendaraan yang akan melewati bagian jalan tertentu pada satu jam (kend/jam).

$$
\mathrm{C}=\mathrm{S} \times \mathrm{g} / \mathrm{c}
$$

Perhitungan derajat kejenuhan (DS) berdasarkan rumus (2) didefinisikan sebagai rasio arus (Q) terhadap kapasitas (C). DS merupakan faktor utama dalam penentuan tingkat kinerja suatu ruas jalan. Nilai DS menunjukkan apakah segmen jalan tersebut mempunyai masalah kapasitas atau tidak. DS untuk jalan perkotaan masih dapat diterima jika DS $<0,75$ (Direktorat Jendral Bina Marga, 1997).

$$
\mathrm{DS}=\mathrm{Q} / \mathrm{C}
$$




\subsubsection{Panjang Antrian}

Panjang antrian dihitung sebagai jumlah yang tersisa pada fase hijau sebelumnya (NQ1) ditambah dengan jumlah kendaraan (smp) yang datang selama fase merah $\left(\mathrm{NQ}_{2}\right)$. Untuk menghitung jumlah antrian $\left(\mathrm{NQ}_{1}\right)$ bisa dihitung setelah mendapatkan nilai derajat kejenuhan.

1. Jika derajat kejenuhan (DS) $>0,5$

$$
\mathrm{NQ}_{1}=0,25 \cdot \mathrm{C} \cdot\left[(\mathrm{DS}-1)+\sqrt{\left.(\mathrm{DS}-1)^{2}+\frac{8 \cdot(\mathrm{DS}-0,5)}{C}\right]}\right.
$$

Dimana : $\mathrm{NQ}_{1}$ merupakan jumlah kendaraan (smp) yang tersisa dari fase sebelumnya, DS adalah nilai derajat kejenuhan, GR merupakan rasio hijau (g/c), sedangkan $\mathrm{C}$ adalah kapasitas (smp/jam)

2. Jika derajat kejenuhan $(\mathrm{DS}) \leq 0,5: \mathrm{NQ}_{1}=0$

Yaitu jumlah antrian kendaraan yang datang selama fase merah $\left(\mathrm{NQ}_{2}\right)$ dengan rumus berikut:

$$
\mathrm{NQ}_{2}=\frac{(1-\mathrm{GR})}{(1-\mathrm{GR} \times \mathrm{DS})} \times \frac{\mathrm{Q}}{3600}
$$

Dimana : $\mathrm{NQ}_{2}$ merupakan jumlah kendaraan (smp) selama fase merah.

\subsubsection{Tundaan}

Tundaan merupakan rata-rata waktu tunggu tiap kendaraan yang masuk dalam pendekat dengan persamaan:

$$
\mathrm{D}_{\mathrm{j}}=\mathrm{DT}_{\mathrm{j}}+\mathrm{DG}_{\mathrm{j}}
$$

Dimana DT adalah tundaan yang terjadi karena interaksi lalu-lintas dengan gerakan lainnya pada suatu simpang. Sedangkan DG adalah perlambatan dan percepatan saat membelok pada suatu simpang dan/atau terhenti karena lampu merah.

\section{METODOLOGI PENELITIAN}

Berdasarkan survei pendahuluan, maka pengamatan lamanya waktu siklus dilakukan selama 2 hari pada hari Senin dan Kamis. Peralatan survey yang digunakan adalah jam, meteran, stopwatch, alat perekam dan alat-alat untuk mencatat hasil dari pengamatan. Ada dua macam data yang diperlukan dalam penelitian ini yaitu data primer dan data sekunder.

Data primer pada penelitian ini berupa hasil pengamatan langsung dilapangan antara lain:

a. Survey Geometrik

Maksud dilakukannya survey ini adalah untuk mengetahui kondisi jalan yang akan digunakan dalam perhitungan. Survey yang dilakukan yaitu menghitung lebar badan jalan, lebar bahu jalan, median jalan serta hambatan samping. Pengambilan data pada survey ini menggunakan meteran.

b. Survey Volume Lalu Lintas 
Survey ini dilakukan dengan merekam kondisi persimpangan menggunakan alat rekam digital sehingga didapatkan arus volume lalu lintas pada jam sibuk pagi,siang dan sore.

Target data:

- Volume lalu lintas tiap satuan waktu per 15 menit atau perjam untuk tiap-tiap jenis kendaraan

- Volume jam sibuk untuk setiap bagian waktu, misalnya jam sibuk, pagi, siang, dan sore.

- Persentase penggunaan model tiap jenis kendaraan.

Survei dilaksanakan selama enam jam tiap satu hari kerja, dengan rincian 2 jam pagi hari (pukul 07.00 - 09.00), 2 jam siang hari (pukul 12.00 - 14.00), dan 2 jam sore hari (pukul 16.00 - 18.00). Kemudian tiap jalur dibagi menjadi beberapa sektor sesuai dengan beberapa arah jalan. Jumlah setiap jenis kendaraan yang berada di tiap sektor di data per 15 menit. Dari data per 15 menit tersebut di rekap dalam 1 jam, kemudian di ambil jam puncaknya untuk di analisa.

Data sekunder merupakan data jumlah penduduk kota Padang yang didapatkan secara tidak langsung dari sumber lain yang berguna untuk melengkapi data primer. Jenis perancangan adalah dengan pengaturan secara terpisah isolated dengan waktu tetap atau fix sistem.

\section{HASIL DAN PEMBAHASAN}

\subsection{Analisa Kondisi Eksisting Persimpangan}

\subsubsection{Data Geometrik Eksisting Simpang}

Sketsa dan data geometrik eksisting persimpangan Jalan Syekh Umar Khalil-Bypass Kota Padang bisa dilihat pada Gambar 2 dan Tabel 2.

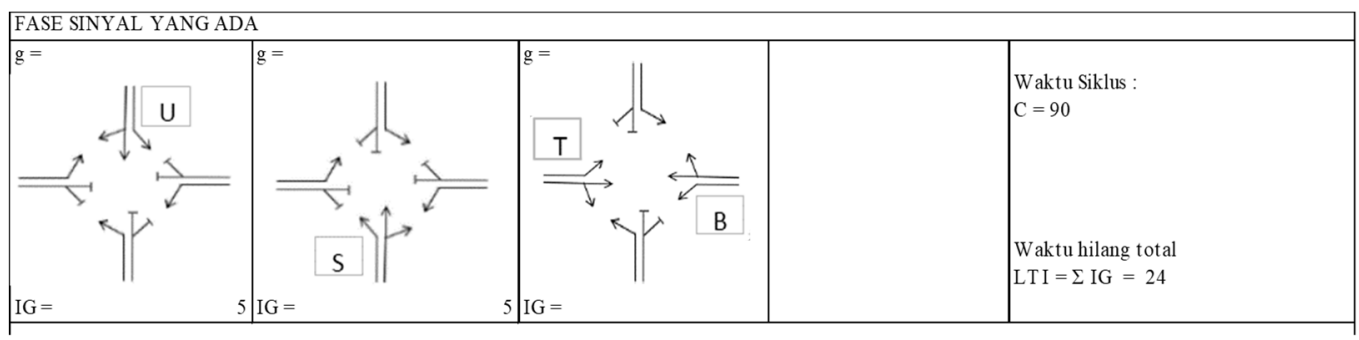

Gambar 2. SIG-I Data Geometrik Eksisting Persimpangan

Simpang jalan Syekh Umar Khalil-Bypass Padang merupakan simpang yang diatur dengan sistem tiga fase sinyal, yang mana untuk pendekat Utara dan Selatan adalah pendekat terlindung dan pendekat Timur dan Barat adalah pendekat terlawan. Pendekat terlindung adalah adalah pendekat yang melewati persimpangan tanpa diikuti oleh pendekat lain. Sedangkan pendekat terlawan bergerak bersamaan dengan pendekat yang lain contohnya pendekat U bergerak bersamaan dengan pendekat $\mathrm{S}$. 
Tabel 2. SIG-I Data Geometrik Eksisting Persimpangan

\begin{tabular}{|c|c|c|c|c|c|c|c|c|c|c|}
\hline \multicolumn{11}{|c|}{ KONDISI LAPANGAN } \\
\hline \multirow[b]{2}{*}{$\begin{array}{c}\text { Kode } \\
\text { Pendekat }\end{array}$} & \multirow{2}{*}{$\begin{array}{c}\text { Tipe } \\
\text { lingkungan } \\
\text { jalan }\end{array}$} & \multirow{2}{*}{\begin{tabular}{|c|} 
Hambatan \\
samping \\
ing gi $\mathrm{i}$ Rendal
\end{tabular}} & \multirow[b]{2}{*}{$\begin{array}{c}\text { Median } \\
\text { Ya/T idak }\end{array}$} & \multirow[b]{2}{*}{$\begin{array}{c}\text { Kelandaian } \\
+/-\%\end{array}$} & \multirow{2}{*}{$\begin{array}{c}\text { Belok kiri } \\
\text { langsumg } \\
\text { Ya/T idak }\end{array}$} & \multirow{2}{*}{$\begin{array}{c}\text { Jarak ke } \\
\text { kendaraan } \\
\text { parkir (m) }\end{array}$} & \multicolumn{4}{|c|}{ Lebar Pendekat (m) } \\
\hline & & & & & & & $\begin{array}{c}\text { Pendekat } \\
W_{A}\end{array}$ & $\begin{array}{c}\text { Masuk } \\
\text { W }_{\text {MASUK }}\end{array}$ & $\begin{array}{l}\text { Belok Kiri } \\
\text { W }_{\text {LTOR }}\end{array}$ & $\begin{array}{c}\text { Keluar } \\
\text { W }_{\text {KELUAR }}\end{array}$ \\
\hline 1 & 2 & 3 & 4 & 5 & 6 & 7 & 8 & 9 & 10 & 11 \\
\hline $\mathrm{U}$ & $\mathrm{COM}$ & $\mathrm{R}$ & $\overline{\mathrm{Y}}$ & & $\mathrm{T}$ & & 5.23 & 5.23 & 0 & 6.23 \\
\hline $\mathrm{S}$ & $\mathrm{COM}$ & $\mathrm{R}$ & $\mathrm{Y}$ & & $\mathrm{T}$ & & 6.43 & 6.43 & 0 & 6.98 \\
\hline $\mathrm{T}$ & $\mathrm{COM}$ & $\mathrm{R}$ & $\mathrm{Y}$ & & $\mathrm{T}$ & & 3.64 & 3.64 & 0 & 3.45 \\
\hline B & RES & $\mathrm{R}$ & $\mathrm{Y}$ & & $\mathrm{T}$ & & 3.37 & 3.37 & 0 & 3.87 \\
\hline
\end{tabular}

\subsubsection{Data Arus Lalu Lintas}

Pengambilan data volume arus lalu lintas dilakukan selama 2 hari, yaitu pada hari Senin dan Kamis. Hasil yang diperoleh menunjukkan bahwa data volume lalu lintas tersibuk pada hari Senin. Hasil data jam tersibuk arus lalu lintas simpang Jalan Syekh Umar Khalil-Bypass dapat dilihat Gambar 3.

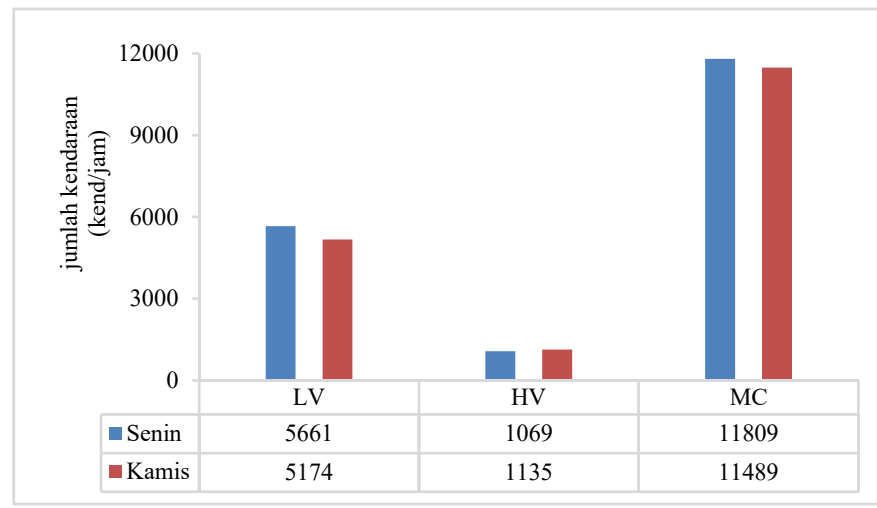

Gambar 3. Arus Lalu Lintas Kendaraan Bermotor pada Jam Puncak

Dari perhitungan arus lalu lintas ini dapat dilihat jumlah kendaraan yang didapatkan berdasarkan dengan kondisi eksisting persimpangan pada jam puncak selama 2 hari penelitian yang akan digunakan untuk mengevaluasi Derajat Kejenuhan, waktu siklus, tundaan, dan lain-lain.

\subsubsection{Faktor Penyesuaian Dan Arus Jenuh Persimpangan}

Jumlah penduduk kota Padang berdasarkan data Badan Pusat Statistik adalah 0,939 Juta Jiwa (Badan Pusat Statistik, 2019). Nilai faktor penyesuaian ukuran kota $\left(\mathrm{F}_{\mathrm{CS}}\right)$ adalah sebesar 0,94. Hambatan Samping $\left(\mathrm{F}_{\mathrm{SF}}\right)$ pada simpang ini rendah, karena tidak banyaknya gangguan dari kendaraan yang berhenti seperti angkot yang menaik turunkan penumpangnya dipinggir jalan, dan toko-toko yang tidak memakan badan jalan. Hasil faktor penyesuaian dan perhitungan arus jenuh, dapat dilihat pada Tabel 3 dan Tabel 4 pada persimpangan tiap jam puncak dan data dari arus jenuh persimpangan. Dan selanjutnya dari perkalian nilai dasar dan nilai masing-masing faktor penyesuaian ini diperoleh nilai arus jenuh yang disesuaikan. 
Tabel 3. Arus Jenuh Pendekat Jam Puncak Senin

\begin{tabular}{|c|c|c|c|c|c|c|c|c|c|c|}
\hline \multirow{4}{*}{$\begin{array}{l}\text { Jam } \\
\text { Puncak }\end{array}$} & \multirow{4}{*}{$\begin{array}{l}\text { Pendek } \\
\text { at }\end{array}$} & \multirow{4}{*}{$\begin{array}{c}\begin{array}{c}\text { Lebar } \\
\text { Efektif } \\
(\mathrm{m})\end{array} \\
\mathrm{W}_{\mathrm{e}}\end{array}$} & \multirow{4}{*}{$\begin{array}{c}\begin{array}{c}\text { Nilai } \\
\text { Dasar }\end{array} \\
\text { So }\end{array}$} & \multirow{2}{*}{\multicolumn{6}{|c|}{$\begin{array}{c}\text { Arus Jenuh smp/jam hijau } \\
\text { Faktor Penyesuaian }\end{array}$}} & \multirow{4}{*}{$\begin{array}{c}\text { Nilai } \\
\text { disesuai } \\
\text { kan } \\
\text { (smp/ja } \\
\text { m) hijau } \\
\text { S }\end{array}$} \\
\hline & & & & & & & & & & \\
\hline & & & & \multicolumn{4}{|c|}{ Semua Tipe Pendekat } & \multicolumn{2}{|c|}{$\begin{array}{l}\text { Hanya } \\
\text { Tipe P }\end{array}$} & \\
\hline & & & & $\mathbf{F}_{\mathrm{CS}}$ & $F_{S F}$ & $\mathbf{F}_{\mathrm{G}}$ & $F_{P}$ & $F_{R T}$ & $\mathbf{F}_{\mathrm{LT}}$ & \\
\hline \multirow[t]{4}{*}{ Pagi } & $\mathrm{U}$ & 7,95 & 4770 & 0,94 & 0,95 & 1 & 1 & 1 & 1 & 4260 \\
\hline & $\mathbf{S}$ & 9,7 & 5820 & 0,94 & 0,95 & 1 & 1 & 1 & 0,9 & 5041 \\
\hline & $\mathrm{T}$ & 4,41 & 2084 & 0,94 & 0,95 & 1 & 1 & 1 & 1 & 1861 \\
\hline & B & 4,12 & 1460 & 0,94 & 0,98 & 1 & 1 & 1 & 1 & 1345 \\
\hline \multirow[t]{4}{*}{ Siang } & $\mathrm{U}$ & 7,95 & 4770 & 0,94 & 0,95 & 1 & 1 & 1 & 1 & 4260 \\
\hline & $\mathbf{S}$ & 9,7 & 5820 & 0,94 & 0,95 & 1 & 1 & 1 & 1 & 5197 \\
\hline & $\mathrm{T}$ & 4,41 & 2244 & 0,94 & 0,95 & 1 & 1 & 1 & 1 & 2004 \\
\hline & B & 4,12 & 1848 & 0,94 & 0,98 & 1 & 1 & 1 & 1 & 1702 \\
\hline \multirow[t]{4}{*}{ Sore } & $\mathrm{U}$ & 7,95 & 4770 & 0,94 & 0,95 & 1 & 1 & 1 & 1 & 4260 \\
\hline & $\mathbf{S}$ & 9,7 & 5820 & 0,94 & 0,95 & 1 & 1 & 1 & 1 & 5197 \\
\hline & $\mathrm{T}$ & 4,41 & 2221 & 0,94 & 0,95 & 1 & 1 & 1 & 1 & 1983 \\
\hline & B & 4,12 & 1725 & 0,94 & 0,98 & 1 & 1 & 1 & 1 & 1589 \\
\hline
\end{tabular}

Tabel 4. Arus Jenuh Pendekat Jam Puncak Kamis

\begin{tabular}{|c|c|c|c|c|c|c|c|c|c|c|}
\hline \multirow{4}{*}{$\begin{array}{l}\text { Jam } \\
\text { Puncak }\end{array}$} & \multirow{4}{*}{ Pendekat } & \multirow{4}{*}{$\begin{array}{c}\text { Lebar } \\
\text { Efektif } \\
(\mathrm{m})\end{array}$} & \multirow{3}{*}{$\begin{array}{l}\text { Nilai } \\
\text { Dasar }\end{array}$} & \multirow{2}{*}{\multicolumn{6}{|c|}{$\begin{array}{c}\text { Arus Jenuh smp/jam hijau } \\
\text { Faktor Penyesuaian }\end{array}$}} & \multirow{4}{*}{$\begin{array}{c}\text { Nilai } \\
\text { disesuaikan } \\
\text { (smp/jam) } \\
\text { hijau } \\
\text { S }\end{array}$} \\
\hline & & & & & & & & & & \\
\hline & & & & Semua & Tipe & end & & \multicolumn{2}{|c|}{$\begin{array}{l}\text { Hanya } \\
\text { Tipe P }\end{array}$} & \\
\hline & & & $S_{O}$ & $\mathrm{~F}_{\mathrm{CS}}$ & $\mathbf{F}_{\mathrm{SF}}$ & $F_{G}$ & $\mathbf{F}_{\mathrm{P}}$ & $F_{R T}$ & $\mathbf{F}_{\mathrm{LT}}$ & \\
\hline \multirow{4}{*}{ Pagi } & $\mathrm{U}$ & 7,95 & 4770 & 0,94 & 0,95 & 1 & 1 & 1 & 1 & 4260 \\
\hline & $\mathbf{S}$ & 9,7 & 5820 & 0,94 & 0,95 & 1 & 1 & 1 & 0,97 & 50411 \\
\hline & $\mathrm{T}$ & 4,41 & 2084 & 0,94 & 0,95 & 1 & 1 & 1 & 1 & 2151 \\
\hline & B & 4,12 & 1460 & 0,94 & 0,98 & 1 & 1 & 1 & 1 & 1999 \\
\hline \multirow{4}{*}{ Siang } & $\mathrm{U}$ & 7,95 & 4770 & 0,94 & 0,95 & 1 & 1 & 1 & 1 & 4260 \\
\hline & $\mathbf{S}$ & 9,7 & 5820 & 0,94 & 0,95 & 1 & 1 & 1 & 1 & 5197 \\
\hline & $\mathrm{T}$ & 4,41 & 2244 & 0,94 & 0,95 & 1 & 1 & 1 & 1 & 2032 \\
\hline & B & 4,12 & 1848 & 0,94 & 0,98 & 1 & 1 & 1 & 1 & 1756 \\
\hline \multirow{4}{*}{ Sore } & $\mathrm{U}$ & 7,95 & 4770 & 0,94 & 0,95 & 1 & 1 & 1 & 1 & 4260 \\
\hline & $\mathbf{S}$ & 9,7 & 5820 & 0,94 & 0,95 & 1 & 1 & 1 & 1 & 5197 \\
\hline & $\mathrm{T}$ & 4,41 & 2221 & 0,94 & 0,95 & 1 & 1 & 1 & 1 & 2014 \\
\hline & B & 4,12 & 1725 & 0,94 & 0,98 & 1 & 1 & 1 & 1 & 1632 \\
\hline
\end{tabular}

Berdasarkan perhitungan arus jenuh pada persimpangan didapatkan nilai arus jenuh yang disesuaikan pada pendekat Selatan, mempunyai nilai yang tinggi untuk kesemua jam sibuk baik pada hari Senin maupun hari Kamis, sehingga diperlukan alternatif perancangan untuk mengurangi tundaan dan antrian yang terjadi.

\subsubsection{Rasio Arus (FR) dan Rasio Fase (PR)}

Nilai rasio arus dihitung dengan membagi nilai arus lalu lintas dengan nilai arus jenuh yang sudah disesuaikan sedangkan rasio fase didapat dengan cara membagi rasio arus dengan jumlah total nilai rasio arus. 
Hasil perhitungan rasio arus lalu lintas dapat dilihat pada Tabel 5 dan 6.

Tabel 5. Rasio Arus Lalu Lintas Senin

\begin{tabular}{|c|c|c|c|c|c|c|c|c|}
\hline \multirow{3}{*}{$\begin{array}{l}\text { Jam } \\
\text { Punca } \\
\mathbf{k}\end{array}$} & \multicolumn{4}{|c|}{ Rasio Arus $(F R=Q / S)$} & \multicolumn{4}{|c|}{$\begin{array}{l}\text { Rasio Fase } \\
\text { (PR=Frcrit/IFR) }\end{array}$} \\
\hline & \multicolumn{4}{|c|}{ Pendekat } & \multicolumn{4}{|c|}{ Pendekat } \\
\hline & $\mathrm{U}$ & $\mathbf{S}$ & $\mathbf{T}$ & B & $\mathrm{U}$ & $\mathbf{S}$ & $\mathrm{T}$ & B \\
\hline Pagi & 0,32 & 0,2 & 0,23 & 0,10 & 0,39 & 0,35 & 0,27 & 0,27 \\
\hline Siang & 0,31 & 0,26 & 0,13 & 0,06 & 0,44 & 0,37 & 0,19 & 0,19 \\
\hline Sore & 0,36 & 0,32 & 0,14 & 0,10 & 0,44 & 0,39 & 0,17 & 0,17 \\
\hline
\end{tabular}

Tabel 6. Rasio Arus Lalu Lintas Kamis

\begin{tabular}{|c|c|c|c|c|c|c|c|c|}
\hline \multirow{3}{*}{$\begin{array}{l}\text { Jam } \\
\text { Punca } \\
\mathbf{k}\end{array}$} & \multicolumn{4}{|c|}{ Rasio Arus $(\mathrm{FR}=\mathrm{Q} / \mathrm{S})$} & \multicolumn{4}{|c|}{$\begin{array}{l}\text { Rasio Fase } \\
\text { (PR=Frcrit/IFR) }\end{array}$} \\
\hline & \multicolumn{4}{|c|}{ Pendekat } & \multicolumn{4}{|c|}{ Pendekat } \\
\hline & $\mathrm{U}$ & $\mathbf{S}$ & $\mathbf{T}$ & B & $\mathrm{U}$ & $\mathbf{S}$ & $\mathrm{T}$ & B \\
\hline Pagi & 0,28 & 0,29 & 0,10 & 0,06 & 0,42 & 0,43 & 0,15 & 0,15 \\
\hline Siang & 0,28 & 0,23 & 0,11 & 0,06 & 0,45 & 0,37 & 0,18 & 0,18 \\
\hline Sore & 0,34 & 0,33 & 0,14 & 0,06 & 0,42 & 0,41 & 0,17 & 0,17 \\
\hline
\end{tabular}

Berdasarkan perhitungan kondisi eksisting, nilai rasio arus dan rasio fase yang diperoleh pada dua hari penelitian berbeda ini dikarenakan berbedanya volume lalu lintas dan arus jenuh dasar yang diperoleh.

\subsubsection{Waktu Siklus dan Waktu Hijau}

Hasil nilai perhitungan waktu siklus saat sebelum penyesuaian $\left(\mathrm{C}_{\mathrm{ua}}\right)$ adalah besar dari 200 detik seperti terlihat pada Tabel 7 dan Gambar 3. Berdasarkan MKJI 1997 waktu siklus tersebut melebihi waktu siklus yang disarankan. Hal ini terjadi karena nilai Rasio arus simpang (IFR) yang begitu besar.

Tabel 7. Nilai Waktu Hijau Berdasarkan Pengamatan dilapangan

\begin{tabular}{lcccc}
\hline \multirow{2}{*}{ Jam Puncak } & \multicolumn{4}{c}{ Waktu hijau (det) } \\
\cline { 2 - 5 } & U & S & T & B \\
\cline { 2 - 5 } & 30 & 30 & 15 & 15 \\
\hline Pagi & 30 & 30 & 15 & 15 \\
\hline Siang & 30 & 30 & 15 & $15 \mathrm{n}$ \\
\hline Sore & &
\end{tabular}

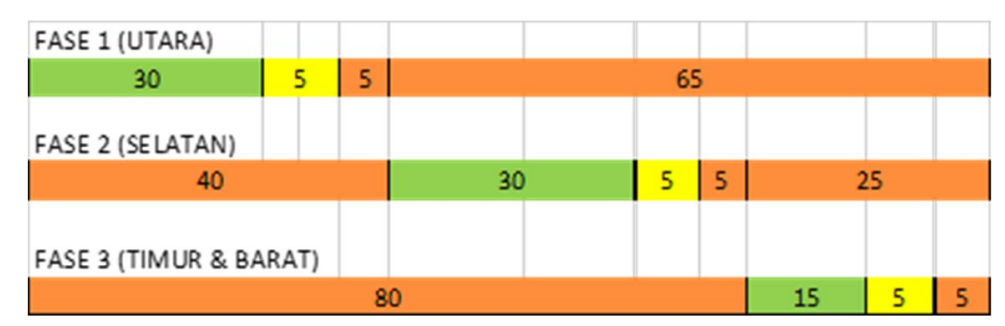

Gambar 3. Waktu Siklus Tiap Fase

\subsubsection{Kapasitas (C) dan Derajat Kejenuhan (DS)}

Dari hasil perhitungan yang didapat berdasarkan keadaan dilapangan, kondisi pendekat secara keseluruhan sudah jenuh, karena rata-rata Derajat Kejenuhan, DS $>1$. 
Tabel 8. Kapasitas dan Derajat Kejenuhan Setiap Pendekat Senin

\begin{tabular}{lcccccccc}
\hline \multirow{2}{*}{$\begin{array}{c}\text { Jam } \\
\text { Punca }\end{array}$} & \multicolumn{3}{c}{ Kapasitas $(\mathbf{C}=\mathbf{S} \times \mathbf{~ g} / \mathbf{c})$} & \multicolumn{5}{c}{$\begin{array}{c}\text { Derajat Kejenuhan } \\
\text { Q/C) }\end{array}$} \\
\cline { 2 - 9 } & \multicolumn{3}{c}{ Pendekat } & \multicolumn{4}{c}{ Pendekat } \\
\hline Pagi & $\mathbf{U}$ & S & T & B & U & S & T & B \\
\hline Siang & 1217 & 1485 & 258 & 131 & 1,14 & 1,02 & 1,58 & 0,73 \\
\hline Sore & 1217 & 1485 & 286 & 243 & 1,09 & 0,90 & 0,93 & 0,40 \\
\hline
\end{tabular}

Tabel 9. Kapasitas dan Derajat Kejenuhan Setiap Pendekat Kamis

\begin{tabular}{ccccccccc}
\hline \multirow{2}{*}{$\begin{array}{c}\text { Jam } \\
\text { Punca }\end{array}$} & \multicolumn{3}{c}{ Kapasitas $(\mathbf{C}=\mathbf{S} \times \mathbf{~ g} / \mathbf{c})$} & \multicolumn{5}{c}{$\begin{array}{c}\text { Derajat Kejenuhan } \\
\text { Q/C) }\end{array}$} \\
\cline { 2 - 9 } & \multicolumn{4}{c}{ Pendekat } & \multicolumn{5}{c}{ Pendekat } \\
\cline { 2 - 9 } & U & S & T & B & U & S & T & B \\
\hline Pagi & 1217 & 1440 & 307 & 286 & 1,00 & 1,02 & 0,73 & 0,40 \\
\hline Siang & 1217 & 1485 & 290 & 251 & 0,97 & 0,80 & 0,78 & 0,42 \\
\hline Sore & 1217 & 1470 & 288 & 233 & 1,20 & 1,16 & 0,95 & 0,43 \\
\hline
\end{tabular}

Seperti yang terdapat pada Tabel 8 dan 9, nilai derajat kejenuhan yang didapat pada keadaan exsisting untuk tiap-tiap pendekat telah melewati batas jenuh yang telah ditetapkan sehingga perlu dilakukan perencanaan ulang lampu lalu lintas pada persimpangan ini agar dapat mengurangi permasalahan yang akan terjadi seperti panjangnya antrian dan besarnya tundaan.

\subsection{Analisis Perencanaan Alat Pemberi Isyarat Lalu Lintas (APILL)}

Pada penelitian ini terdapat nilai Derajat Kejenuhan yang melewati batas jenuh pada persimpangan. Maka dilakukanlah beberapa langkah dalam usaha menurunkannya, sehingga dapat mengurangi panjangnya antrian dan besarnya tundaan yang terjadi.

\subsubsection{Perencanaan Kondisi I (Pelebaran)}

Perencanaan untuk kondisi I ini adalah dengan pengaspalan bahu jalan sehingga menambah lebar jalan dan meningkatkan kapasitas simpang dan diharapkan dapat menurunkan Derajat Kejenuhan (Alhani, Erwan, \& Sulandari, 2017). Berdasarkan kondisi lapangan perencanaan ini dilakukan pengaspalan pada bahu jalan selebar 1,5 meter. Dengan dilakukannya pelebaran jalan, maka $\mathrm{W}_{\text {masuk }}$ akan mengalami perubahan, sehingga nilai derajat kejenuhan yang didapatkan akan menurun dibandingkan kondisi eksisting. Nilai derajat kejenuhan yang diperoleh dapat dilihat pada tabel 10.

Tabel 10. Derajat Kejenuhan Perencanaan Kondisi I

\begin{tabular}{lcccccccc}
\hline \multirow{3}{*}{$\begin{array}{c}\text { Jam } \\
\text { Puncak }\end{array}$} & \multicolumn{4}{c}{ Senin } & \multicolumn{5}{c}{ Kamis } \\
\cline { 2 - 9 } & \multicolumn{4}{c}{ Derajat Kejenuhan (DS = Q/C) } & \multicolumn{5}{c}{ Derajat Kejenuhan (DS = Q/C) } \\
\cline { 2 - 9 } & $\mathbf{U}$ & S & T & B & U & S & T & B \\
\hline Pagi & 0,89 & 0,87 & 1,47 & 0,67 & 0,78 & 0,87 & 0,68 & 0,37 \\
\hline Siang & 0,86 & 0,77 & 0,77 & 0,31 & 0,76 & 0,68 & 0,72 & 0,39 \\
\hline Sore & 0,99 & 0,96 & 0,83 & 0,58 & 0,93 & 1,00 & 0,88 & 0,40 \\
\hline
\end{tabular}

Pada perencanaan ini, nilai waktu nyala hijau berbeda dengan kondisi eksisting, dimana waktu hijau pada perencanaan ini adalah 40 detik untuk pendekat Utara dan Selatan dan 20 detik untuk pendekat Timur dan Barat. 
Nilai derajat kejenuhan terbesar terdapat pada jam puncak sore dimana pada hari Senin untuk pendekat Utara 0,99 dan Selatan 0,96 sedangkan untuk pendekat Timur 0,83 dan Barat 0,58, dan pada hari Kamis untuk pendekat Utara 0,93, pendekat Selatan 1,00, pendekat Timur 0,88 dan pendekat Barat 0,40.

Tabel 11. Jumlah Kendaraan Antri, Panjang Antrian, Jumlah Kendaraan Henti dan Tundaan (Senin)

\begin{tabular}{|c|c|c|c|c|c|c|c|}
\hline $\begin{array}{l}\text { Jam } \\
\text { Punca } \\
\text { k }\end{array}$ & $\begin{array}{c}\text { Pendeka } \\
t\end{array}$ & $\begin{array}{c}\text { Kendaraa } \\
\text { n Antri } \\
\text { (smp) }\end{array}$ & $\begin{array}{l}\text { Panjan } \\
\mathbf{g} \\
\text { Antrian } \\
(\mathrm{m})\end{array}$ & $\begin{array}{c}\text { Jumlah } \\
\text { Kend } \\
\text { Henti } \\
\text { (smp/det } \\
\text { ) }\end{array}$ & $\begin{array}{c}\text { Rata-rata } \\
\text { Kend } \\
\text { Henti } \\
\text { (stop/smp } \\
\text { ) }\end{array}$ & $\begin{array}{c}\text { Tundaan } \\
\text { (smp/det } \\
\text { ) }\end{array}$ & $\begin{array}{c}\text { Tundaa } \\
\mathbf{n} \\
\text { Simpang } \\
\text { Rata- } \\
\text { rata } \\
\end{array}$ \\
\hline \multirow{4}{*}{ Pagi } & $\mathrm{U}$ & 51,18 & 160 & 1279 & \multirow{4}{*}{1,42} & 1270 & \multirow{4}{*}{2,69} \\
\hline & $\mathrm{S}$ & 54,57 & 145 & 1360 & & 1316 & \\
\hline & $\mathrm{T}$ & 85,76 & 345 & 2137 & & 6545 & \\
\hline & B & 5,28 & 58 & 132 & & 151 & \\
\hline \multirow{4}{*}{ Siang } & $\mathrm{U}$ & 47,46 & 154 & 1183 & \multirow{4}{*}{0,87} & 1140 & \multirow{4}{*}{0,85} \\
\hline & $\mathrm{S}$ & 44,91 & 133 & 1119 & & 1040 & \\
\hline & $\mathrm{T}$ & 10,45 & 82 & 260 & & 308 & \\
\hline & B & 2,83 & 39 & 71 & & 80 & \\
\hline \multirow{4}{*}{ Sore } & $\mathrm{U}$ & 73,20 & 160 & 1824 & \multirow{4}{*}{1,09} & 2309 & \multirow{4}{*}{1,29} \\
\hline & $\mathrm{S}$ & 68,99 & 145 & 1719 & & 1907 & \\
\hline & $\mathrm{T}$ & 11,79 & 100 & 294 & & 363 & \\
\hline & $\mathrm{B}$ & 5,76 & 68 & 144 & & 159 & \\
\hline
\end{tabular}

Tabel 11 dan Tabel 12 memperlihatkan nilai masing-masing jumlah kendaraan terhenti berupa Angka Henti (NS), Panjang Antrian (QL), jumlah total dari kendaraan antri (NQ), Jumlah Kendaraan Henti (NSv) untuk masing-masing pendekat, dan Tundaan pada perencanaan kondisi II untuk hari Senin dan Kamis.

Seperti terlihat pada Tabel 11, untuk jumlah kendaraan antri terbanyak mencapai lebih dari 85,76 smp, panjang antrian terpanjang yaitu 345 meter, rata-rata kendaraan terhenti dan tundaan rata-rata nilai pada perencanaan kondisi II yang mencapai 1,42 stop/smp, tundaan rata-rata 2,69 smp.det.

Selanjutnya untuk perhitungan jumlah kendaraan yang antri, panjang antrian, jumlah kendaraan henti dan tundaan pada hari Kamis dapat dilihat pada Tabel 12.

Tabel 12. Jumlah Kendaraan Antri, Panjang Antrian, Jumlah Kendaraan Henti dan Tundaan (Kamis)

\begin{tabular}{|c|c|c|c|c|c|c|c|}
\hline $\begin{array}{c}\text { Jam } \\
\text { Punc } \\
\text { ak }\end{array}$ & Pendekat & $\begin{array}{l}\text { Kendar } \\
\text { aan } \\
\text { Antri } \\
(\mathrm{smp})\end{array}$ & $\begin{array}{l}\text { Panjang } \\
\text { Antrian } \\
\text { (m) }\end{array}$ & $\begin{array}{c}\text { Jumlah } \\
\text { Kend } \\
\text { Henti } \\
\text { (smp/det } \\
\text { ) }\end{array}$ & $\begin{array}{c}\text { Rata-rata } \\
\text { Kend } \\
\text { Henti } \\
\text { (stop/smp } \\
\text { ) }\end{array}$ & $\begin{array}{c}\text { Tundaan } \\
\text { (smp/det } \\
\text { ) }\end{array}$ & $\begin{array}{l}\text { Tundaan } \\
\text { Simpang } \\
\text { Rata-rata }\end{array}$ \\
\hline \multirow{4}{*}{ Pagi } & $\mathrm{U}$ & 41,07 & 133 & 1023 & \multirow{4}{*}{0,87} & 954 & \multirow{4}{*}{0,85} \\
\hline & $S$ & 52,85 & 145 & 1317 & & 1276 & \\
\hline & $\mathrm{T}$ & 8,27 & 73 & 206 & & 234 & \\
\hline & B & 3,49 & 49 & 87 & & 97 & \\
\hline \multirow{4}{*}{ Siang } & $\mathrm{U}$ & 39,69 & 131 & 989 & \multirow{4}{*}{0,83} & 918 & \multirow{4}{*}{0,79} \\
\hline & $S$ & 38,10 & 114 & 949 & & 870 & \\
\hline & $\mathrm{T}$ & 8,53 & 73 & 212 & & 246 & \\
\hline & $\mathrm{B}$ & 3,21 & 39 & 80 & & 89 & \\
\hline Sore & $\mathrm{U}$ & 56,87 & 160 & 1417 & 1,08 & 1477 & 1,30 \\
\hline
\end{tabular}

58 | JURNAL REKAYASA SIPIL 


\begin{tabular}{|c|c|c|c|c|c|c|c|}
\hline \multirow[t]{4}{*}{$\begin{array}{c}\text { Jam } \\
\text { Punc } \\
\text { ak }\end{array}$} & Pendekat & $\begin{array}{c}\text { Kendar } \\
\text { aan } \\
\text { Antri } \\
(\mathrm{smp})\end{array}$ & $\begin{array}{c}\text { Panjang } \\
\text { Antrian } \\
\text { (m) }\end{array}$ & $\begin{array}{l}\text { Jumlah } \\
\text { Kend } \\
\text { Henti } \\
\text { (smp/det }\end{array}$ & $\begin{array}{c}\text { Rata-rata } \\
\text { Kend } \\
\text { Henti } \\
\text { (stop/smp }\end{array}$ & $\begin{array}{c}\text { Tundaan } \\
\text { (smp/det } \\
\text { ) }\end{array}$ & $\begin{array}{l}\text { Tundaan } \\
\text { Simpang } \\
\text { Rata-rata }\end{array}$ \\
\hline & $\mathrm{S}$ & 81,95 & 145 & 2042 & & 2624 & \\
\hline & $\mathrm{T}$ & 12,31 & 100 & 307 & & 404 & \\
\hline & $B$ & 3,12 & 39 & 78 & & 86 & \\
\hline
\end{tabular}

Kondisi pada hari Kamis jumlah kendaraan antri terbanyak mencapai lebih 81,95 smp, panjang antrian terpanjang yaitu 160 meter, rata-rata kendaraan terhenti dan tundaan ratarata adalah 1,08 stop/smp, tundaan rata-rata 1,30 smp.det.

Seperti terlihat pada Tabel 11 dan Tabel 12, untuk jumlah kendaraan antri tertinggi terdapat pada hari Senin yang mencapai lebih dari $85 \mathrm{smp}$ dengan panjang antriannya yaitu 345 meter, sehingga perencanaan dengan pelebaran ini, derajat kejenuhan yang diperoleh masih melebihi batas syarat yang telah ditetapkan sehingga masih belum memenuhi kondisi syarat sebuah persimpangan, maka perencanaan ini belum dapat diterima.

\subsubsection{Perencanaan Kondisi II (Pengaturan 2 fase)}

Pada perencanaan ini persimpangan akan diatur dengan sistem 2 fase dimana untuk pendekat Utara dan Selatan bergerak bersamaan sehingga akan menjadi pendekat terlawan (O). Nilai waktu hijau pada perencanaan ini berbeda dengan perencanaan kondisi I sehingga derajat kejenuhan yang diperoleh akan menurun dibandingkan kondisi sebelumnya. Nilai derajat kejenuhan pada perencanaan kondisi II ini disajikan pada tabel 13.

Tabel 13. Derajat Kejenuhan Perencanaan Kondisi II

\begin{tabular}{lcccccccc}
\hline \multirow{2}{*}{$\begin{array}{c}\text { Jam } \\
\text { Puncak }\end{array}$} & \multicolumn{4}{c}{ Senin } & \multicolumn{4}{c}{ Kamis } \\
\cline { 2 - 9 } & \multicolumn{3}{c}{ Derajat Kejenuhan $(\mathbf{D S}=\mathbf{Q} / \mathbf{C})$} & \multicolumn{4}{c}{ Derajat Kejenuhan $(\mathrm{DS}=\mathbf{Q} / \mathbf{C})$} \\
\cline { 2 - 9 } & $\mathbf{U}$ & $\mathbf{S}$ & $\mathbf{T}$ & $\mathbf{B}$ & $\mathbf{U}$ & $\mathbf{S}$ & $\mathbf{T}$ & $\mathbf{B}$ \\
\hline Pagi & 0,85 & 0,71 & 0,85 & 0,39 & 0,90 & 0,72 & 0,39 & 0,21 \\
\hline Siang & 0,94 & 0,61 & 0,50 & 0,21 & 0,75 & 0,53 & 0,42 & 0,22 \\
\hline Sore & 0,90 & 0,79 & 0,54 & 0,39 & 1,09 & 0,78 & 0,51 & 0,23 \\
\hline
\end{tabular}

Dengan sistem pengaturan 2 fase pendekat Utara dan Selatan akan menjadi pendekat terlawan dimana kendaraan akan sama-sama berangkat. Pada pengaturan 2 fase ini, waktu hijau untuk pendekat Utara dan Selatan adalah 68 detik dan pendekat Timur dan Barat adalah 32 detik, sehingga derajat kejenuhan yang diperoleh telah menurun dibandingkan pada perencanaan I. Nilai derajat kejenuhan tertinggi terdapat pada jam puncak sore, yaitu pada Senin sore untuk Utara 0,90, Selatan 0,79, timur 0,54, dan Barat 0,39, pada Kamis sore derajat kejenuhan pendekat Utara 1,09, Selatan 0,78, timur 0,51, dan Barat 0,23.

Untuk nilai jumlah kendaraan antri, Panjang Antrian, Jumlah Kendaraan Henti dan Tundaan pada perencanaan kondisi II secara terperinci terdapat dalam Tabel 14 untuk hari Senin dan Tabel 15 untuk hari Kamis. 
Tabel 14. Jumlah Kendaraan Antri, Panjang Antrian, Jumlah Kendaraan Henti dan Tundaan (Senin)

\begin{tabular}{|c|c|c|c|c|c|c|c|}
\hline $\begin{array}{c}\text { Jam } \\
\text { Punca } \\
\mathbf{k}\end{array}$ & Pendekat & $\begin{array}{c}\text { Kendaraan } \\
\text { Antri } \\
\text { (smp) }\end{array}$ & $\begin{array}{c}\text { Panjang } \\
\text { Antrian (m) }\end{array}$ & $\begin{array}{l}\text { Jumlah } \\
\text { Kend. } \\
\text { Henti } \\
\text { (smp/det) }\end{array}$ & $\begin{array}{l}\text { Rata-rata } \\
\text { Kend Henti } \\
\text { (stop/smp) }\end{array}$ & $\begin{array}{l}\text { Tundaan } \\
\text { (smp/det) }\end{array}$ & $\begin{array}{l}\text { Tundaan } \\
\text { Simpang } \\
\text { Rata-rata }\end{array}$ \\
\hline \multirow{4}{*}{ Pagi } & $\mathrm{U}$ & 55,32 & 191 & 1494 & \multirow{4}{*}{0,75} & 941 & \multirow{4}{*}{0,50} \\
\hline & $\mathrm{S}$ & 48,48 & 151 & 11309 & & 750 & \\
\hline & $\mathrm{T}$ & 15,58 & 113 & 421 & & 438 & \\
\hline & B & 3,64 & 44 & 98 & & 89 & \\
\hline \multirow{4}{*}{ Siang } & $\mathrm{U}$ & 55,36 & 191 & 1495 & \multirow{4}{*}{0,76} & 1089 & \multirow{4}{*}{0,53} \\
\hline & $\mathrm{S}$ & 35,33 & 111 & 954 & & 539 & \\
\hline & $\mathrm{T}$ & 7,54 & 54 & 204 & & 184 & \\
\hline & $\mathrm{B}$ & 2,15 & 39 & 58 & & 57 & \\
\hline \multirow{4}{*}{ Sore } & $\mathrm{U}$ & 59,93 & 191 & 1618 & \multirow{4}{*}{0,78} & 1069 & \multirow{4}{*}{0,51} \\
\hline & $\mathrm{S}$ & 53,93 & 157 & 1456 & & 851 & \\
\hline & $\mathrm{T}$ & 8,20 & 73 & 221 & & 200 & \\
\hline & B & 4,35 & 49 & 117 & & 106 & \\
\hline
\end{tabular}

Kendaraan antri, panjang antrian tertinggi terdapat pada jam puncak sore pada hari Kamis seperti terlihat pada Tabel 15, dimana kendaraan antri mencapai $155 \mathrm{smp}$, panjang antrian 201 meter, kendaraan terhenti rata-rata mencapai 1,38 stop/smp dan tundaan simpang ratarata 1,80 smp.detik. Begitu juga, dengan masih tingginya derajat kejenuhan yang didapat maka perencanaan masih belum dapat diterima untuk persimpangan ini.

Tabel 15. Jumlah Kendaraan Antri, Panjang Antrian, Jumlah Kendaraan Henti dan Tundaan (Kamis)

\begin{tabular}{|c|c|c|c|c|c|c|c|}
\hline $\begin{array}{c}\text { Jam } \\
\text { Punc } \\
\text { ak }\end{array}$ & $\begin{array}{c}\text { Pende } \\
\text { kat }\end{array}$ & $\begin{array}{c}\text { Kendaraa } \\
\text { n Antri } \\
\text { (smp) }\end{array}$ & $\begin{array}{c}\text { Panjang } \\
\text { Antrian } \\
\text { (m) }\end{array}$ & $\begin{array}{c}\text { Jumlah } \\
\text { Kend Henti } \\
\text { (smp/det) }\end{array}$ & $\begin{array}{c}\text { Rata-rata } \\
\text { Kend } \\
\text { Henti } \\
\text { (stop/smp } \\
\text { ) }\end{array}$ & $\begin{array}{c}\text { Tundaan } \\
\text { (smp/det) }\end{array}$ & $\begin{array}{l}\text { Tundaan } \\
\text { Simpang } \\
\text { Rata-rata }\end{array}$ \\
\hline \multirow{4}{*}{ Pagi } & $\mathrm{U}$ & 51,33 & 191 & 1386 & \multirow{4}{*}{0,75} & 924 & \multirow{4}{*}{0,48} \\
\hline & $\mathrm{S}$ & 46,91 & 144 & 1266 & & 719 & \\
\hline & $\mathrm{T}$ & 5,99 & 54 & 162 & & 146 & \\
\hline & $\mathrm{B}$ & 2,56 & 39 & 70 & & 68 & \\
\hline \multirow{4}{*}{ Siang } & $\mathrm{U}$ & 36,15 & 141 & 976 & \multirow{4}{*}{0,63} & 571 & \multirow{4}{*}{0,39} \\
\hline & $\mathrm{S}$ & 28,89 & 95 & 780 & & 437 & \\
\hline & $\mathrm{T}$ & 6,05 & 59 & 163 & & 148 & \\
\hline & $\mathrm{B}$ & 2,36 & 29 & 64 & & 62 & \\
\hline \multirow{4}{*}{ Sore } & $\mathrm{U}$ & 155,17 & 201 & 4190 & \multirow{4}{*}{1,38} & 6558 & \multirow{4}{*}{1,80} \\
\hline & $\mathrm{S}$ & 552,84 & 157 & 1427 & & 831 & \\
\hline & $\mathrm{T}$ & 7,70 & 73 & 208 & & 188 & \\
\hline & B & 2,28 & 29 & 62 & & 60 & \\
\hline
\end{tabular}

\subsubsection{Perencanaan Kondisi III (Pengaturan 2 Fase dan Pelebaran)}

Untuk perencanaan ini pelebaran yang dilakukan sama dengan pelebaran pada perencanaan kondisi I yaitu 1,5 meter. Waktu hijau dan waktu hilang total pada perencanaan ini sama dengan perencanaan kondisi II. Nilai derajat kejenuhan yang didapatkan pada perencanaan ini terdapat pada Tabel 16. Selanjutnya Tabel 17 dan 18 merupakan perhitungan Jumlah Kendaraan Antri, Panjang Antrian, Jumlah Kendaraan Henti dan Tundaan untuk hari Senin dan Kamis. 
Tabel 16. Derajat Kejenuhan Perencanaan Kondisi III

\begin{tabular}{ccccccccc}
\hline & \multicolumn{3}{c}{ Senin } & \multicolumn{4}{c}{ Kamis } \\
\hline \multirow{2}{*}{ Jam } & \multicolumn{3}{c}{ Derajat Kejenuhan $(\mathbf{D S}=\mathbf{Q} / \mathbf{C})$} & \multicolumn{4}{c}{ Derajat Kejenuhan $(\mathbf{D S}=\mathbf{Q} / \mathbf{C})$} \\
\cline { 2 - 9 } Puncak & \multicolumn{4}{c}{ Pendekat } & Pendekat & T \\
\cline { 2 - 9 } & $\mathbf{U}$ & $\mathbf{S}$ & $\mathbf{T}$ & $\mathbf{B}$ & $\mathbf{S}$ & $\mathbf{T}$ & $\mathbf{B}$ \\
\hline Pagi & 0,72 & 0,68 & 0,85 & 0,39 & 0,73 & 0,69 & 0,39 & 0,21 \\
\hline Siang & 0,76 & 0,59 & 0,50 & 0,21 & 0,62 & 0,51 & 0,42 & 0,22 \\
\hline Sore & 0,86 & 0,77 & 0,54 & 0,39 & 0,97 & 0,74 & 0,51 & 0,23 \\
\hline
\end{tabular}

Tabel 17. Jumlah Kendaraan Antri, Panjang Antrian, Jumlah Kendaraan Henti dan Tundaan (Senin)

\begin{tabular}{|c|c|c|c|c|c|c|c|}
\hline $\begin{array}{l}\text { Jam } \\
\text { Puncak }\end{array}$ & $\begin{array}{c}\text { Pendek } \\
\text { at }\end{array}$ & $\begin{array}{c}\text { Kendaraa } \\
\text { n Antri } \\
\text { (smp) }\end{array}$ & $\begin{array}{l}\text { Panjan } \\
\mathbf{g} \\
\text { Atrian } \\
\text { (m) }\end{array}$ & $\begin{array}{c}\text { Jumlah } \\
\text { Kend Henti } \\
\text { (smp/det) }\end{array}$ & $\begin{array}{c}\text { Rata- } \\
\text { rata } \\
\text { Kend } \\
\text { Henti } \\
\text { (stop/sm } \\
\text { p) } \\
\end{array}$ & $\begin{array}{c}\text { Tundaan } \\
\text { (smp/det } \\
\text { ) }\end{array}$ & $\begin{array}{l}\text { Tundaan } \\
\text { Simpang } \\
\text { Rata-rata }\end{array}$ \\
\hline \multirow{4}{*}{ Pagi } & $\mathrm{U}$ & 46,76 & 147 & 1262 & \multirow{4}{*}{0,69} & 757 & \multirow{4}{*}{0,45} \\
\hline & $\mathrm{S}$ & 47,00 & 135 & 1269 & & 719 & \\
\hline & $\mathrm{T}$ & 15,44 & 118 & 417 & & 430 & \\
\hline & B & 3,62 & 39 & 98 & & 89 & \\
\hline \multirow{4}{*}{ Siang } & $\mathrm{U}$ & 41,55 & 135 & 1122 & \multirow{4}{*}{0,65} & 656 & \multirow{4}{*}{0,40} \\
\hline & $\mathrm{S}$ & 34,68 & 103 & 936 & & 528 & \\
\hline & $\mathrm{T}$ & 7,54 & 73 & 204 & & 184 & \\
\hline & B & 2,15 & 29 & 58 & & 57 & \\
\hline \multirow{4}{*}{ Sore } & $\mathrm{U}$ & 56,22 & 160 & 1518 & \multirow{4}{*}{0,75} & 960 & \multirow{4}{*}{0,48} \\
\hline & $\mathrm{S}$ & 52,55 & 145 & 1419 & & 822 & \\
\hline & $\mathrm{T}$ & 8,20 & 73 & 221 & & 200 & \\
\hline & B & 4,35 & 49 & 117 & & 106 & \\
\hline
\end{tabular}

Tabel 18. Jumlah Kendaraan Antri, Panjang Antrian, Jumlah Kendaraan Henti dan Tundaan (Kamis)

\begin{tabular}{|c|c|c|c|c|c|c|c|}
\hline $\begin{array}{c}\text { Jam } \\
\text { Puncak }\end{array}$ & Pendekat & $\begin{array}{c}\text { Kendara } \\
\text { an Antri } \\
(\mathrm{smp})\end{array}$ & $\begin{array}{c}\text { Panjang } \\
\text { Atrian } \\
\text { (m) }\end{array}$ & $\begin{array}{c}\text { Jumlah } \\
\text { Kend } \\
\text { Henti } \\
\text { (smp/det) }\end{array}$ & $\begin{array}{c}\text { Rata-rata } \\
\text { Kend } \\
\text { Henti } \\
\text { (stop/smp } \\
\text { ) }\end{array}$ & $\begin{array}{l}\text { Tundaan } \\
\text { (smp/det) }\end{array}$ & $\begin{array}{l}\text { Tundaan } \\
\text { Simpang } \\
\text { Rata-rata }\end{array}$ \\
\hline \multirow{4}{*}{ Pagi } & $\mathrm{U}$ & 40,94 & 131 & 1105 & \multirow{4}{*}{0,67} & 667 & \multirow{4}{*}{0,41} \\
\hline & $\mathrm{S}$ & 45,74 & 133 & 1235 & & 697 & \\
\hline & $\mathrm{T}$ & 5,99 & 59 & 152 & & 146 & \\
\hline & $\mathrm{B}$ & 2,59 & 29 & 70 & & 68 & \\
\hline \multirow{4}{*}{ Siang } & $\mathrm{U}$ & 31,66 & 105 & 855 & \multirow{4}{*}{0,59} & 483 & \multirow{4}{*}{0.36} \\
\hline & $\mathrm{S}$ & 28,47 & 84 & 769 & & 431 & \\
\hline & $\mathrm{T}$ & 6,05 & 59 & 163 & & 148 & \\
\hline & B & 2,71 & 29 & 64 & & 62 & \\
\hline \multirow{4}{*}{ Sore } & $\mathrm{U}$ & 72,16 & 160 & 1948 & \multirow{4}{*}{0,85} & 1598 & \multirow{4}{*}{0,62} \\
\hline & $\mathrm{S}$ & 50,94 & 145 & 1375 & & 793 & \\
\hline & $\mathrm{T}$ & 7,70 & 73 & 208 & & 188 & \\
\hline & B & 2,28 & 29 & 62 & & 60 & \\
\hline
\end{tabular}

Untuk perencanaan pelebaran yang dilakukan pada kondisi ini sama dengan perencanaan I dan waktu hijau yang direncanakan sama dengan perencanaan kondisi II. Nilai derajat kejenuhan yang didapat berdasarkan perencanaan dengan sistem 2 fase dan pelebaran ini 
telah memenuhi syarat untuk sebuah persimpangan dan panjang antrian kendaraan telah berada dibawah 150 meter.

Tetapi jika dilihat jumlah kendaraan antri untuk pendekat Utara dan Selatan yang begitu besar dibanding dengan pendekat Barat dan Timur maka diusulkan untuk menutup simpang tersebut dan disediakan bukaan median bagi kendaraan yang ingin berputar arah.

\subsubsection{Perencanaan Kondisi IV (Menutup SImpang Jalan)}

Perencanaan kondisi IV ini direncanakan adanya penutupan simpang dengan memperpanjang median jalan dan simpang ini tidak lagi menggunakan lampu lalu lintas, sehingga kendaraan yang akan berpindah jalur baik dari arah Utara ke Selatan atau sebaliknya dan kendaraan yang akan berbelok dari Timur ke Selatan atau Barat ke Utara harus berputar arah terlebih dahulu.

Tabel 19. Arus Lalu lintas Kendaraan Belok Kanan

\begin{tabular}{|c|c|c|c|c|c|c|c|c|}
\hline \multicolumn{5}{|c|}{ Senin } & \multicolumn{4}{|c|}{ Kamis } \\
\hline $\begin{array}{c}\text { Jam } \\
\text { Puncak }\end{array}$ & $\begin{array}{c}\text { Kend } \\
\text { belok } \\
\text { kanan } \\
\text { dari } \\
\text { arah } \\
\text { Timur }\end{array}$ & $\begin{array}{c}\text { Kend } \\
\text { belok } \\
\text { kanan } \\
\text { dan } \\
\text { berputa } \\
\text { r dari } \\
\text { arah } \\
\text { Utara }\end{array}$ & $\begin{array}{c}\text { Kend } \\
\text { belok } \\
\text { kanan } \\
\text { dari } \\
\text { arah } \\
\text { Barat }\end{array}$ & $\begin{array}{c}\text { kend } \\
\text { belok } \\
\text { kanan } \\
\text { dan } \\
\text { berputa } \\
\text { r dari } \\
\text { arah } \\
\text { Selatan }\end{array}$ & $\begin{array}{c}\text { Kend } \\
\text { belok } \\
\text { kanan } \\
\text { dari } \\
\text { arah } \\
\text { Timur }\end{array}$ & $\begin{array}{c}\text { kend } \\
\text { belok } \\
\text { kanan } \\
\text { dan } \\
\text { berputa } \\
\text { r dari } \\
\text { arah } \\
\text { Utara }\end{array}$ & $\begin{array}{c}\text { Kend } \\
\text { belok } \\
\text { kanan } \\
\text { dari } \\
\text { arah } \\
\text { Barat }\end{array}$ & $\begin{array}{c}\text { kend } \\
\text { belok } \\
\text { kanan } \\
\text { dan } \\
\text { berputa } \\
\text { r dari } \\
\text { arah } \\
\text { Selatan }\end{array}$ \\
\hline Pagi & 417 & 60 & 108 & 108 & 88 & 86 & 93 & 282 \\
\hline Siang & 261 & 70 & 71 & 303 & 229 & 56 & 80 & 220 \\
\hline Sore & 295 & 83 & 97 & 301 & 279 & 56 & 14 & 278 \\
\hline Total & 973 & 213 & 276 & 712 & 596 & 198 & 187 & 780 \\
\hline
\end{tabular}

Seperti terlihat pada Tabel 19, dengan tidak adanya lampu merah maka akan menghilangkan tingginya nilai derajat kejenuhan, panjang antrian dan tundaan yang didapat pada kondisi eksisting seperti yang terdapat pada Tabel 8 dan 9 (kapasitas dan Derajat Kejenuhan Setiap Pendekat pada hari Senin dan Kamis).

\section{KESIMPULAN DAN SARAN}

\subsection{Kesimpulan}

Berdasarkan dari hasil perencanaan dan perhitungan yang telah dilakukan terhadap kondisi persimpangan, maka dapat disimpulkan:

1. Evaluasi kondisi Eksisting

Banyaknya kendaraan yang melewati persimpangan ini, setelah dilakukan evaluasi pada kondisi eksisting, didapatkan hasil masing-masing pendekat Utara, Selatan dan Timur untuk nilai derajat kejenuhannya rata-rata $\geq 1$, yang mana telah melewati batas derajat kejenuhan yang diizinkan yaitu, 0,75 . Sedangkan untuk pendekat Barat nilai derajat kejenuhannya masih dibawah batas jenuh yang telah ditentukan.

2. Pelebaran jalur pendekat.

Pada perencanaan ini nilai derajat kejenuhan pada pendekat Utara, Selatan dan Timur masih belum memenuhi batas syarat kejenuhan sebuah simpang hanya pendekat Barat yang telah memenuhi syarat batas jenuh, maka diperlukan perencanaan lain.

3. Pengaturan 2 Fase 
Dengan pengaturan perencanaan 2 fase, derajat kejenuhan yang didapat telah menurun dibandingkan dengan perencanaan sebelumnya tetapi pada pendekat Utara untuk masing-masing jam puncak masih melebihi batas derajat kejenuhan yang diizinkan sehingga diperlukan alternatif perencanaan lainnya.

4. Pengaturan 2 Fase dan pelebaran

Pengaturan simpang dengan sistem 2 fase ditambah pelebaran nilai derajat kejenuhan yang diperoleh telah berada dibawah batas syarat kejenuhan persimpangan dan hanya pendekat Utara pada jam puncak sore saja yang masih melebihi batas jenuh. Dengan mempertimbangkan tingginya waktu siklus yang didapatkan maka perencanaan inilah yang dapat diterima untuk simpang jalan Syekh Umar Khalil-Bypass Kota Padang.

5. Menutup Simpang Jalan

Dengan menutup simpang jalan dan memperpanjang median jalan dan bukaan median yang dibuka pada jarak 100 meter dari kaki simpang maka kendaraan yang akan bepindah jalur diharuskan berputar terlebih dahulu sehingga tidak akan ada nilai derajat kejenuhan, panjang antrian dan tundaan kendaraan, karena tidak adanya lampu lalu lintas.

Maka rekomendasi untuk persimpangan ini adalah menggunakan alat pemberi isyarat lalu lintas (APILL) dengan menggunakan pengaturan 2 fase dan pelebaran karena derajat kejenuhan yang diperoleh dibawah batas syarat kejenuhan untuk 3 pendekat, kecuali pendekat utara. Disamping itu pengaturan sinyal lalu lintas dengan dua fase ini akan memberikan kapasitas yang lebih besar. Tetapi, karena jumlah volume lalu lintas untuk pendekat minor yang sedikit, maka menutup simpang mungkin lebih baik sehingga tidak akan ada nilai derajat kejenuhan, panjang antrian dan tundaan kendaraan.

\subsection{Saran}

1. Perlu dilakukan perubahan terhadap waktu hijau pada masing-masing pendekat dan pelebaran pada badan jalan, sehingga dapat mengurangi panjangnya antrian dan tundaan yang terlalu lama.

2. Perlu dilakukan perencanaan ulang, sehingga apabila terjadi peningkatan jumlah kendaraan tidak akan menimbulkan permasalahan dan pelanggaran-pelanggaran pada persimpangan jalan ini.

3. Untuk mencegah tingginya derajat kejenuhan makan lebih baik simpang ditutup dan median jalan diperpanjang dan bukaan median dapat dibuka sesuai dengan syarat yang ada.

\section{DAFTAR PUSTAKA}

Alhani, Erwan, K., \& Sulandari, E. (2017). Analisa Lalu Lintas Terhadap Kapasitas Jalan di Pinggiran Kota Pontianak (Kasus Jalan Sungai Raya Dalam). Jurnal Mahasiswa Teknik Sipil Universitas Tanjungpura, 4(4).

Badan Pusat Statistik. (2019). Statistik Daerah Kota Padang. Padang: BPS Kota Padang.

Direktorat Jendral Bina Marga. (1997). Manual Kapasitas Jalan Indonesia 1997. Jakarta: Departemen Pekerjaan Umum.

Khairunnisa, N. F., EPF, A. Y., Priyono, E. Y., \& Supriyono. (2017). Evaluasi Kinerja Lalu Lintas Simpang di Jalan Layang Dan Bundaran Kalibanteng, Semarang dengan Nilai Ekuivalensi Mobil Penumpang Simpang Bersinyal Terkoreksi. Jurnal Karya Teknik Sipil, 6(2), 107-117.

Khisty, C. J., \& Lall, B. K. (2005). Dasar-dasar Rekayasa Transportasi Jilid 1. Jakarta: Erlangga. 
Mahendra, A. D., Khairi, M., Arifin, M. Z., \& Sulistio, H. (2015). Kajian Persebaran Lalu Lintas Akibat Pembongkaran Jembatan Soekarno Hatta. Jurnal Mahasiswa Jurusan Teknik Sipil, $1-11$.

Munandar, A. (2012). Persepsi masyarakat terhadap alat pemberi isyarat lalu lintas (APILL) sistem counter down traffic light dalam menciptakan perilaku tertib berkendara di kota Yogyakarta. (Skripsi), Universitas Negeri Yogyakarta,

Pradipta, Eka, R., \& Purba, T. (2016). Evaluasi Kinerja Simpang Bersinyal dan Flyover di Bundaran Kallibanteng. (Tugas Akhir), Universitas Diponegoro, Semarang.

Royan, N. (2015). Analisa perencanaan traffic light di persimpangan bandara SMB II Palembang. Berkala Teknik, 5(2).

Utama, I. W. P. P., Sumanjaya, G., \& Ardantha, M. (2017). Perencanaan alat pemberi isyarat lampu lalu lintas (APILL) pada persimpangan jalan pulau galang, jalan taman pancing dan jalan tukud baru Paduraksa, 6(2). 